The Capsular group B Meningococcal Vaccine, 4CMenB: Clinical Experience and Potential Efficacy

Christine S. Rollier, Oxford Vaccine Group, Department of Paediatrics, University of Oxford, and the NIHR Biomedical Research Centre, Churchill Hospital, Oxford, OX3 7LE, UK $\mathrm{PhD}$, Post-doctoral research associate, Meningococcal projects, Oxford Martin fellow and Jenner Institute Investigator

Christina Dold, Oxford Vaccine Group, Department of Paediatrics, University of Oxford, and the NIHR Biomedical Research Centre, Churchill Hospital, Oxford, OX3 7LE, UK $\mathrm{PhD}$, Post-doctoral fellow, Meningococcal projects

Leanne Marsay, Oxford Vaccine Group, Department of Paediatrics, University of Oxford, and the NIHR Biomedical Research Centre, Churchill Hospital, Oxford, OX3 7LE, UK $\mathrm{PhD}$, Post-doctoral fellow, Meningococcal projects

Manish Sadarangani, Oxford Vaccine Group, Department of Paediatrics, University of Oxford, and the NIHR Biomedical Research Centre, Churchill Hospital, Oxford, OX3 7LE, UK BM BCh MRCPCH DPhil, Clinical Lecturer in Paediatric Infectious Diseases and Immunology

Andrew J Pollard* Oxford Vaccine Group, Department of Paediatrics, University of Oxford, and the NIHR Biomedical Research Centre, Churchill Hospital, Oxford, OX3 7LE, UK MRCP FRCPCH PhD, Professor of Paediatric Infection and Immunity, director Oxford Vaccine Group

*Corresponding author: $\quad$ Tel +44 (0)1865 234226 
Fax $+44(0) 1865234235$

andrew.pollard@paediatrics.ox.ac.uk

\title{
The Capsular group B Meningococcal Vaccine, 4CMenB: Clinical Experience and Potential Efficacy
}

\begin{abstract}
Introduction. Capsular group B meningococcal disease is a leading cause of childhood meningitis and septicaemia. Up to $10 \%$ of sufferers die, and sequelae remain in more than $30 \%$ of survivors. A vaccine, $4 \mathrm{CMenB}$, designed with the aim to induce broad coverage against this highly variable bacterium, has been licensed in countries including in the European Union, Canada and Australia. Areas covered. Immunogenicity and safety data, published in peer-reviewed literature between 2004 and 2014, are presented in the context of the recent recommendation for the use of the vaccine in infants in the UK.

Expert opinion. $4 \mathrm{CMenB}$ induces significant reactogenicity when administered with routine infant vaccines, in particular with respect to fever rates. Fevers can be somewhat reduced using paracetamol. The efficacy of the vaccine is unknown but has been extrapolated from effectiveness data obtained from use of one of its components in New Zealand, immunogenicity data from clinical trials and estimation of coverage from in vitro studies. These data suggest that the vaccine will prevent a proportion of invasive meningococcal disease cases in infants and young children. Implementation and well-planned post-marketing surveillance will address uncertainties over field effectiveness.
\end{abstract}


Keywords: Four component meningococcal group B vaccine (4CMenB), Meningococcal disease, Outer membrane vesicles, Recombinant proteins, capsular group B meningococcus, Vaccine 


\section{Introduction}

Neisseria meningitidis causes approximately 500,000 cases of meningococcal meningitis and septicaemia globally every year, with a peak incidence in children under 2 years1,2. Adverse outcomes are common, with a case-fatality rate of $10 \%$ in resource-rich settings, and $30 \%$ of survivors suffer severe long-term disability including deafness, amputation and cognitive impairment. The casefatality rate has not decreased significantly since the 1950s3, despite advances in medical care and increased education of the public and healthcare professionals. Vaccination is the optimal way to reduce the mortality and morbidity from this disease. The organism is categorised into groups on the basis of its polysaccharide capsule, with most disease caused by groups A, B, C, W, X and Y4. There are currently effective polysaccharide-protein conjugate vaccines available against capsular groups A, $\mathrm{C}, \mathrm{W}$ and $\mathrm{Y}$ organisms, which are used in Europe (group $\mathrm{C}$ vaccine), North America (group C and groups ACWY vaccines) and Australias. The majority of disease in Europe, Australia and Canada is now therefore caused by capsular group B strains (MenB, 85-90\% of cases in the UK)5. The capsular group B polysaccharide consists of a polysialic acid, which is poorly immunogenic because it is identical to polysialic acid found on foetal brain tissue6. Effective vaccines based on outer membrane vesicles (OMVs) have been used to tackle strain-specific epidemics in Cuba, New Zealand and a hyper-endemic outbreak in France7. OMVs are produced naturally by $N$. meningitidis, and contain the outer membrane components, including the protective but strain-specific and highly variable antigen porin A (PorA)7. The efficacy of these vaccines was largely restricted to the vaccine strain and provided only a limited degree of cross-protection against strains containing heterologous PorA variants in older individuals but not in infants7. Such vaccines would be unlikely to provide broad protection in countries with endemic disease and a wide range of circulating group B strains, such as the UK, but are more suited to the outbreak situations in which they have been used 7. There is therefore a need for a MenB vaccine with a potential for broad-spectrum coverage, i.e. the ability to protect against a wide range of circulating strains. $4 \mathrm{CMenB}$ has been developed with this aim, and has the 
additional advantage that inclusion of multiple antigens not only increases breadth of coverage but reduces the likelihood that an organism can escape from vaccine-induced immunity by variation of a single antigen. It has now been licensed in several countries including in the European Union, Australia and Canada4. A regional campaign has started in 2014 in Québec's Saguenay-Lac-Saint-Jean region, where $4 \mathrm{CMenB}$ is being offered to individuals from 2 months to 20 years of age 8 . In March 2014 the UK Joint Committee on Vaccination and Immunisation (JCVI), which reports to the UK Department of Health, made a recommendation based on cost-effectiveness that the vaccine should be included as part of the UK routine immunisation schedule, given to children at 2, 4 and 12 months of age 9

\section{Overview of the market}

Invasive meningococcal disease is rare, and the average incidence in the UK has been decreasing in the past decade (on average 1.8/100.100 per year in the period 2006-20124). In the US, there is currently an even lower rate of disease, with 0.15 cases per 100,000 reported in the year 201210. However, recent outbreaks at Universities in Ohio, New Jersey and California underline the potential use of a MenB vaccine in the USA11, and $4 \mathrm{CMenB}$ is currently being used in two of these universities under a treatment Investigational New Drug designation in an effort to control these outbreaks. The highest MenB incidence is observed in infants, peaking around 5 months of age, and a second smaller peak is observed at around 18 years12. Therefore, young children and adolescents, being at most risk, are the primary target for vaccination in the countries where prevalence of MenB is 1-2 cases per 100,000 (Europe, Canada and the South-American countries) 13, 14.

In some countries, cost-effectiveness is not a major part of the process for adoption of a new vaccine programme but in others, such as the UK, cost-effectiveness analysis is a key issue 4. Calculating the cost-effectiveness is hampered by the limited or absent data on costs to the health service, vaccine efficacy and duration of protection 15 . Several models were used to estimate the cost-effectiveness of 4CMenB (evaluating scenarios for both adolescent and/or infant programmes); A scenario involving 
an infant 3-dose immunization program, assuming 95\% efficacy, 88\% strain coverage and 36 month duration of protection was predicted to be cost-effective in the UK16, 17. Conversely, in The Netherlands, where the rate of disease is lower than in the UK, $4 \mathrm{CMenB}$ was deemed not cost-effective 18. Another vaccine with a potential for broad protection is in clinical development: a MenABCWY meningococcal vaccine combining $4 \mathrm{CMenB}$ with the MenACWY conjugate vaccine, is currently in phase II clinical trials19. This vaccine is thus designed to induce protection against the majority of invasive disease-causing strains worldwide. Several countries are only using monovalent MenC or MenA vaccines as a result of local epidemiological data (e.g. MenA is the predominant cause of disease in subSaharan Africa), while others already have established routine programmes containing MenACWY5. The United States Food and Drug Administration (FDA) has granted "Breakthrough Therapy" designation to both this vaccine candidate and to $4 \mathrm{CMenB}$, thus allowing fast track development program features and intensive FDA guidance. Another MenB vaccine designed to induce broad protection has been developed for adolescents20. It contains two variants of the outer membrane lipoprotein factor $\mathrm{H}$ binding protein (FHbp, also referred as rLP2086 in this vaccine) and has been approved by the FDA in October 2014 to prevent invasive meningococcal disease caused by Neisseria meningitidis serogroup B in individuals 10 through 25 years of age.

\section{Composition of $4 \mathrm{CMenB}$.}

4CMenB contains 4 components, three of which are recombinant outer membrane proteins: Neisseria adhesin A (NadA) group I, FHbp variant 1.1 and Neisserial heparin binding antigen (NHBA) variant 24. NHBA and FHbp are fused to two other outer membrane proteins GNA1030 and GNA2091 respectively. The fourth component is OMVs derived from the New Zealand epidemic strain NZ98/254, chemically detoxified (MeNZB), 21. Every dose contains 50 $\mu$ g each of NadA, FHbp- 
GNA2091 and NHBA-GNA1030 in addition to $25 \mu \mathrm{g}$ of OMVs. The vaccine is formulated with $1.5 \mathrm{mg}$ $\mathrm{Al}(\mathrm{OH})_{3}$ in $10 \mathrm{mM}$ histidine buffer containing $110-120 \mathrm{mM}$ saline.

\section{Safety and tolerability.}

\subsection{Fever rates in infants}

4CMenB has been administered to over 7500 infants, children, adolescents and adults (Table 1). Fever rates $(\geq 38 \mathrm{oC})$ of $26-41 \%$ are reported when $4 \mathrm{CMenB}$ is administered alone to 2 months old infants, which is not significantly higher than MeNZB (16-37\% in infants 6 to 10 weeks of age and 9-11\% in 16 to 24 month old toddlers) 21-24. However, most use of the vaccine will be in the context of concomitant administration with routine vaccines, which increases the risk of systemic reactions substantially22, 25: incidence rates of fever were $51-61 \%(\geq 38 \mathrm{oC})$ in phase $\mathrm{IIb}$, and $65.3 \%(\geq 38.5 \mathrm{oC})$ in phase III, compared to $23-36 \%$ and $32.2 \%$ respectively for routine vaccines alone, though the fevers generally resolved within 2 days (Table 2)22, 25. This effect was less pronounced in earlier phase II trials 26, 27. Prophylactic paracetamol is recommended by the JCVI for infants receiving the combination of $4 \mathrm{CMenB}$ and routine infant vaccines (upon vaccination and a further 2 doses 4 to 6 hours apart): a Phase II trial showed no clinically significant effects of the paracetamol on the immune responses to the vaccines 28 . Incidence of fever $\geq 38.5 \mathrm{o}$ after the primary dose of $4 \mathrm{CMenB}$ with routine vaccines decreased to $39 \%$ from $70 \%$ when paracetamol was used as compared to $27 \%$ in infants receiving routine vaccines with MenC without paracetamol28.

\subsection{Systemic effects in adolescents/adults}

Headaches were reported by $42 \%$ of adolescents following $4 \mathrm{CMenB}$ immunisation compared with $27 \%$ in those receiving a placebo 29 . These rates are high in comparison to those reported for human papilloma virus (HPV) vaccine in adolescent, 9.2\% and 10.6\% in the vaccine and placebo groups respectively30. However, the most common adverse event (AE) was transient malaise, with $51 \%$ of 
immunised participants affected compared to $30 \%$ of those receiving the placebo30. In a study of 53 adults, 4 to 5 participants remained at home after each dose and 5 to 10 required antipyretic/analgesic medication 31.

\subsection{Local reactions}

4CMenB induces severe local tenderness in all age groups, with higher rates ( 9 to $15 \%$ ) than have been reported for the OMV vaccines MeNZB and MenBvac, compared with rates of 1-3\% with routine vaccines28, 32. Previously, fear of pain and adverse events with other vaccines has been identified as an important barrier limiting vaccination compliance in children33. Reactogenicity is increased when $4 \mathrm{CMenB}$ is co-administered with routine vaccines, incidence rates of severe pain were reported as 12 $16 \%$ in phase IIb (infants), $24-29 \%$ in phase III (infants), $14-15 \%$ in phase III (toddlers) and $17 \%$ in adolescents 25-27, 29. In preschool children receiving two doses of 4CMenB, 91 and $92 \%$ reported pain after 1 or 2 doses respectively, severe in $10-13 \%$ of the children for up to 3 days. Pain was still reported at day 7 in $19 \%$ of participants34. These results are similar to induration reactions reported in adults31.

\subsection{Unsolicited adverse events}

During Phase III studies, four possibly vaccine-related febrile seizures and one case of Kawasaki disease were reported as possibly related to the study vaccine in one trial 22. In another Phase III trial, two cases of febrile seizures were defined as probably related to the vaccine and four cases of Kawasaki disease possibly related to $4 \mathrm{CMenB}_{25}$. All AEs deemed to be related to $4 \mathrm{CMenB}$ resolved by the end of the studies. The febrile convulsions are likely to be directly related to the vaccines but the relationship with Kawasaki disease still remains uncertain at this stage.

\section{Clinical immunogenicity and expected coverage}


Efficacy can only be adequately measured in a phase III controlled clinical trial, but the low incidence of disease makes it unlikely that such a study could ever be undertaken4. Only the effectiveness of the OMV component of the vaccine has thus far been evaluated $(73 \%$ observed in New Zealand for MeNZB)35. For this reason, the potential efficacy must be estimated from immunogenicity data and accepted correlates of protection. The latter is estimated by using a serum bactericidal activity against selected target strains, with an exogenous human complement source (hSBA), titres $\geq 1: 4$ being the assumed correlate of protection used for vaccine licensure4. However, titres can differ among laboratories36. Use of this assay is hampered by the small volumes of serum available from infant studies, and difficulties in sourcing a suitable exogenous human complement for each strain tested. Therefore the assay is routinely performed only against a small selection of strains, and it is difficult to derive firm conclusions about activity against the population of disparate bacterial strains that cause disease, complicated by different expression levels of the target antigens between strains.

\subsection{Immunogenicity}

The results of the Phase II clinical trials demonstrated that $4 \mathrm{CMenB}$ is immunogenic in children, with the proportion of vaccinees achieving protective SBA titres varying from 85 to $95 \%$ depending on the target strain used, 1 month after the third dose26. Furthermore, a fourth booster dose elicited anamnestic responses, with the proportion of subjects with protective titres reaching 93 to $100 \%$ depending on the strain used 26. In the analysis used by JCVI a short-term vaccine efficacy of $95 \%$ was considered a plausible estimate9.

\subsection{Expected coverage}

Infants immunised with $4 \mathrm{CMenB}$ at 2 and 4 months had hSBA titres $\geq 1: 4$ against strains expressing homologous PorA, NadA and FHbp as well as related antigenic variants of NadA and FHbp 26. Due to serum volume limitations in infant studies, a reductionist approach was adopted in which four MenB 
indicator strains were selected for SBA testing to measure the contribution of each antigen: 44/76-SL for FHbp, 5/99 for NadA, NZ98/254 for PorA, M10713 for NHBA, each primarily expressing one 4CMenB-specific antigen variant but mismatched for the remaining three37, except for NZ98/254 which also contains an homologous NHBA. However immunization with NHBA does not elicit bactericidal activity against this strain, which therefore measures the contribution of PorA-specific antibodies37. Strain M10713 has only relatively recently been incorporated into the immunogenicity analysis plans and thus not all trials have results for this strain. In addition, the meningococcal antigen typing system (MATS) was developed with the aim of measuring both the quantity of target expressed on the surface of the bacterial strains and the binding activity of the antibody raised by the vaccine. For PorA, which is constitutively expressed, the variable loops are sequenced. For the other antigens, a sandwich ELISA is performed 38 39: In one study I was shown that MATS may underestimate the potential activity against meningococcal strains measured using hSBA40. Using MATS, estimates of 66-91.2\% for coverage of the vaccine for disease-causing strains in various countries were predicted (Table 3). The largest study to assess strain coverage using MATS estimated that $78 \%$ of European strains $(\mathrm{n}=1052)$ might be covered by $4 \mathrm{CMenB} 39$. .While highly dependent on a given country's circulating strains, studies predict that cross-protective bactericidal activity will be elicited by NHBA (21.2-82.6\% of expected coverage), FHbp (7-69\%), PorA (1-21\%) and NadA (0.7-4\%)39, 41, 42. A study using hSBA rather than MATS predicted an overall vaccine strain coverage of $88 \% 40$, and while these predictions, whether from MATS or hSBA, cannot be directly linked to effectiveness data until after an implementation, the latter has been used in the most recent modelling scenarios17. Of note, both SBA and MATS were performed using pooled sera, which may increase the activity detected through synergistic capacity of antibodies from individuals responding to different epitopes.

\subsection{Duration of bactericidal activity}


Because invasion is so rapid following acquisition, persistence of circulatory antibody is important for vaccine efficacy, and immunological memory may have a lesser role. A limited number of studies have assessed the bactericidal antibody persistence conferred by the $4 \mathrm{CMenB}$ vaccine (Table 4 ). Findlow and colleagues26 described waning of hSBA geometric mean titres (GMTs) six months after the last dose of immunisation delivered in a schedule at 2, 4 and 6 months of age: at this time-point, bactericidal activity against all four reference strains had decreased as compared with those measured five months earlier (Table 4, top row). A booster administered at 12 months of age elicited greater bactericidal antibody levels than those observed one month after the third (6 month) dose26. Waning of immunity among those under 2 years of age can therefore be somewhat mitigated by the 12 month toddler dose. However, at 3-4 years of age, SBA GMTs were found to have declined significantly, with the exception of those against $\mathrm{NadA}_{43}$, suggesting that the infant schedule is unlikely to provide sustained bactericidal activity into later childhood and adolescence, and further booster doses would be required to maintain immunity. These results suggest that the estimation of 36 months duration of protection used by recent modeling studies of vaccine impact15, 17, which were based on clinical trials with $4 \mathrm{CMenB}$ and observations from other meningococcal vaccines, may actually be optimistic.

Data on persistence of immunity in teenagers indicate waning of bactericidal antibody titres 18-24 months after the last immunisation, regardless of whether two or three doses were used 44. However, greater duration of bactericidal activity was observed in these older age groups in comparison to the younger cohorts, with hSBA GMTs remaining above pre-immunisation levels44 (Table 4). Currently, there are no data available to indicate how long the hSBA GMTs observed 18-24 months post second immunisation (above the protective threshold) will be maintained. While there is a much lower disease incidence in teenagers than infants limiting the impact of direct protection in this age group, antibody persistence would have considerable importance in population protection if $4 \mathrm{CMenB}$ was able to induce herd protection, i.e. the capacity to decrease carriage rates in adolescents which effectively 
decreases transmission and disease in non-vaccinated individuals, as observed with capsular group C meningococcal vaccine 45.

The antigen-specific waning of bactericidal antibodies in both infants $34,43,46$ and teenagers 44 is of importance in determining the persistence of expected coverage. However, rates of waning are not the same for antibodies directed against each of the 4 vaccine antigens: in vaccinated infants, 20 or 28 months post booster (Table 4, top and second rows), SBA GMTs decreased sharply against PorA and FHbp, while the decrease was less pronounced or absent against NadA and NHBA, as compared with one month post boost34, 43. Bactericidal antibodies titers against strain NZ98/254 (PorA) were below the putative protection threshold 20 months post booster (Table 4)34,43. Bactericidal activity induced by immunisation with FHbp is variable and dependent upon FHbp expression levels in the target strains, and strain 44/76-SL is considered a high expresser of FHbp variant 1.147, 48. Therefore, given hSBA GMTs in children aged five years old who have received a 3+1 schedule have not remained at high levels (4.69 [95\% CI: 1.98-11]) against strain 44/76-SL34, it is unlikely that bactericidal activity against circulating strains will remain against low variant 1 expressors or distantly related variants. SBA titers against 5/99 (NadA) are maintained at high levels in children 34 and teenagers44, but it is unlikely that this will provide much persistent cross-reacting bactericidal activity given the NadA gene is present in only 20-50\% of MenB strains 49, 50. NHBA-specific bactericidal titers are low after vaccination and do not decrease rapidly26, 43 (Table 4). However, contribution of persistence to coverage can only be made with the introduction of routine immunisation.

\subsection{Impact on carriage acquisition}

Post-implementation analyses demonstrated that a major effect of capsular group C meningococcal vaccines was to interrupt transmission51. This effect dramatically enhanced the efficacy and the costeffectiveness of the vaccine51. Whether $4 \mathrm{CMenB}$ induces similar effect is therefore of particular importance as such effect would dramatically increase the effectiveness of 4CMenB. Measuring this 
potential effect is hampered by the need for large number of individuals and acquisition events to accurately power the studies. Currently, sufficient data are not available to determine whether 4CMenB will reduce carriage acquisition and thus curtail transmission. A single Phase III clinical trial (NCT01214850), evaluating the contribution of 4CMenB on N. meningitidis carriage in 18-24 yearolds has recently been completed. It indicated that, from 3 months after two doses, 4CMenB was associated with a modest decrease in carriage of any N. meningitidis strain (18.2\% [95\%CI: 3.4-30.8]), when the data for the time-points 3,5 and 11 months post second vaccine dose were aggregated52. No impact of 4CMenB on capsular group B strains only was observed, and no impact was observed when each time point was analysed separately. This may be due to the low number of capsular group B carriage acquisitions during the study, in addition to the observation that most acquisition events occurred after the first vaccine dose and before the second. Based on these results, JCVI concluded that the impact of $4 \mathrm{CMenB}$ on prevention of carriage acquisition was likely comprised between 0 and $30 \%$, and thus the potential effect at the population level is very difficult to predict at this stage 9.

\section{Conclusion.}

Data from a series of clinical trials demonstrate that $4 \mathrm{CMenB}$ given with the current routine infant vaccines is associated with increased rates of fever, which can be partially reduced by the use of prophylactic paracetamol. The clinical efficacy of the vaccine has been estimated using two in vitro assays (SBA, required for vaccine licensure, and MATS). The immunogenicity data provide strong support for the use of the vaccine to prevent infection caused by strains expressing the vaccine antigens. However, the vaccine coverage remains uncertain for the wider population of meningococci that actually cause disease in each region, though current estimates, ranging from 66 to $88 \%$ in infants provide support for use of the vaccine. In infants, the vaccine should induce bactericidal antibodies through the period of greatest risk of disease, though the impact of differential waning of antibody directed against the four vaccine components remains uncertain. Waning of antibody after infant 
vaccine indicates that protection may not persist through childhood without booster doses. Following introduction of an infant programme, $4 \mathrm{CMenB}$ is likely to prevent a proportion of invasive meningococcal disease in infants and young children: in the best case scenario, $26 \%$ of the cases would be prevented in the first five years following implementation of an infant program as recommended by the JCVI in the UK17. A $48.8 \%$ reduction of cases would be obtained at 10 years if the program included adolescent vaccination and the vaccine provided herd immunity, but the full impact of the vaccine will not be established until after implementation in routine infant vaccination schedules and following careful surveillance and identification of disease-causing strains.

\section{Expert opinion.}

The prospect of reducing the burden from this devastating disease after over 40 years of clinical trials of serogroup B meningococcal vaccines is an important milestone in public health. However, despite the wealth of data currently available about the vaccine, a number of questions remain unanswered. It is not clear if this vaccine will induce herd protection - if it does, population impact will be greater than estimates derived from direct protection. To provide this critical information, carriage studies should be conducted in all populations where the vaccine is introduced, either as part of the routine schedule or to control a specific outbreak. Strain coverage and vaccine efficacy have been estimated from in vitro data, but effectiveness in the field is unknown. The vaccine will protect against strains which express sufficient levels of the specific variants of the vaccine antigens on the surface, but protection against other strains is not known. The ability of MATS or SBA to predict efficacy for subcapsular meningococcal antigens is uncertain, and will only be clear from carefully conducted surveillance post-vaccine implementation. The relatively low rates of disease means it may be several years until this information is clear. Although this vaccine has been licensed as a group B vaccine, the polysaccharide capsule (which defines the group) is not a part of the vaccine. There is therefore the possibility the vaccine will be effective against other capsular groups, as suggested by hSBA titers 
against several capsular group X strains detected in pooled sera from 4CMenB vaccinees53. However, this vaccine will not eliminate all capsular group B meningococcal disease. It is therefore important that research into improved meningococcal vaccines continues, with the aim of inducing broad, longlasting protection against all strains. The rapid evolution of $N$. meningitidis and its ability to evade the immune response makes this an ongoing challenge for vaccine developers. Finally, while the vaccine has proved to be safe in clinical trials, it has resulted in a higher rate of fever in infants when given with currently used vaccines in some studies. Public acceptance of a vaccine for meningitis is likely to be high, but in an era where there is significant vaccine hesitancy in some populations, accurate information about the vaccine will need to be disseminated to ensure that children are completely immunised, local and systemic reactions (especially fever) are minimised with paracetamol, and public confidence in vaccines is preserved. 


\section{Bibliography}

Papers have been highlighted as either of interest $(*)$ or of considerable interest $(* *)$.

1. Nadel S. Prospects for eradication of meningococcal disease. Arch Dis Child 2012 Nov;97(11):993-8.

2. Martin NG, Sadarangani M, Pollard AJ, Goldacre MJ. Hospital admission rates for meningitis and septicaemia caused by Haemophilus influenzae, Neisseria meningitidis, and Streptococcus pneumoniae in children in England over five decades: a population-based observational study. Lancet Infect Dis 2014 May;14(5):397-405.

3. Goldacre MJ, Roberts SE, Yeates D. Case fatality rates for meningococcal disease in an English population, 1963-98: database study. Bmj 2003 Sep 13;327(7415):596-7.

4. Andrews SM, Pollard AJ. A vaccine against serogroup B Neisseria meningitidis: dealing with uncertainty. Lancet Infect Dis 2014 May;14(5):426-34.

5. Halperin SA, Bettinger JA, Greenwood B, Harrison LH, Jelfs J, Ladhani SN, et al. The changing and dynamic epidemiology of meningococcal disease. Vaccine 2012 May 30;30 Suppl 2:B26-36.

6. Finne J, M. Leinonen, and P. H. Makela. Antigenic similarities between brain components and bacteria causing meningitis: Implications for vaccine development and pathogenesis. Lancet 1983;2:355-57.

7. Sadarangani M, Pollard AJ. Serogroup B meningococcal vaccines-an unfinished story. Lancet Infect Dis 2010 Feb;10(2):112-24.

8. Vaccination

SeSS.

http://www.msss.gouv.qc.ca/sujets/santepub/vaccination/index.php?accueil_en. 2014.

9. Department of Health. JCVI position statement on use of Bexsero® meningococcal B vaccine in the UK. 2014.

10. Centers for Disease Control and Prevention. Active bacterial Core surveillance report emerging infections programm network: Neisseria meningitidis. http://wwwcdcgov/abcs/report-findins/survreports/mening12pdf 2012.

11. Mandal S, Wu HM, MacNeil JR, Machesky K, Garcia J, Plikaytis BD, et al. Prolonged university outbreak of meningococcal disease associated with a serogroup B strain rarely seen in the United States. Clin Infect Dis 2013 Aug;57(3):344-8.

12. Ladhani SN, Lucidarme J, Newbold LS, Gray SJ, Carr AD, Findlow J, et al. Invasive meningococcal capsular group Y disease, England and Wales, 2007-2009. Emerging infectious diseases 2012 Jan;18(1):63-70. 
13. Christensen H, May M, Bowen L, Hickman M, Trotter CL. Meningococcal carriage by age: a systematic review and meta-analysis. Lancet Infect Dis 2010 Dec;10(12):853-61.*

* Modelling of the potential impact of group B meningococcal vaccination programs

14. Howitz M, Lambertsen L, Simonsen JB, Christensen JJ, Molbak K. Morbidity, mortality and spatial distribution of meningococcal disease, 1974-2007. Epidemiology and infection 2009 Nov;137(11):1631-40.

15. Christensen H, Hickman M, Edmunds WJ, Trotter CL. Introducing vaccination against serogroup B meningococcal disease: an economic and mathematical modelling study of potential impact. Vaccine 2013 May 28;31(23):2638-46.

16. JCVI statement on the use of meningococcal $C$ vaccines in the routine childhood immunisation

programme. http://webarchivenationalarchivesgovuk/20130107105354/http://wwwdhgovuk/prod_cons um_dh/groups/dh_digitalassets/@dh/@ab/documents/digitalasset/dh_132443pdf 2012.

17. Christensen H, Trotter CL, Hickman M, Edmunds WJ. Re-evaluating cost effectiveness of universal meningitis vaccination (Bexsero) in England: modelling study. Bmj 2014;349:g5725.** ** re-evaluation of the modelling study

18. Pouwels KB, Hak E, van der Ende A, Christensen H, van den Dobbelsteen GP, Postma MJ. Cost-effectiveness of vaccination against meningococcal B among Dutch infants: Crucial impact of changes in incidence. Hum Vaccin Immunother 2013 May;9(5):1129-38.

19. Novartis. A Phase 2b, Randomized, Controlled, Observer-Blind, Multi-Center Study Assessing the Effectiveness, Immunogenicity and Safety of Novartis Meningococcal ABCWY Vaccine Administered to Healthy Adolescents in the U.S. NCT02140762. http://clinicaltrialsgov 2014.

20. Richmond PC, Marshall HS, Nissen MD, Jiang Q, Jansen KU, Garces-Sanchez M, et al. Safety, immunogenicity, and tolerability of meningococcal serogroup B bivalent recombinant lipoprotein 2086 vaccine in healthy adolescents: a randomised, single-blind, placebo-controlled, phase 2 trial. Lancet Infect Dis 2012 Aug;12(8):597-607.

21. Wong SH, Lennon DR, Jackson CM, Stewart JM, Reid S, Ypma E, et al. Immunogenicity and tolerability in infants of a New Zealand epidemic strain meningococcal B outer membrane vesicle vaccine. Pediatr Infect Dis J 2009 May;28(5):385-90.

22. Gossger N, Snape MD, Yu LM, Finn A, Bona G, Esposito S, et al. Immunogenicity and tolerability of recombinant serogroup B meningococcal vaccine administered with or without routine infant vaccinations according to different immunization schedules: a randomized 
controlled trial. JAMA : the journal of the American Medical Association 2012 Feb 8;307(6):57382.**

** Phase II study of 4CMenB administered with routine vaccines in infants

23. Oster $\mathrm{P}$, et al. $\mathrm{MeNZB}^{\mathrm{TM}}$ : a safe and highly immunogenic taylor-made vaccine against the New Zealand Neisseria meningitidis serogroup B disease epidemic strain. Vaccine 2005;23:2191-96.

24. Wong S, Lennon D, Jackson C, Stewart J, Reid S, Crengle S, et al. New zealand epidemic strain meningococcal B outer membrane vesicle vaccine in children aged 16-24 months. Pediatr Infect Dis J 2007 Apr;26(4):345-50.

25. Vesikari T, Esposito S, Prymula R, Ypma E, Kohl I, Toneatto D, et al. Immunogenicity and safety of an investigational multicomponent, recombinant, meningococcal serogroup B vaccine (4CMenB) administered concomitantly with routine infant and child vaccinations: results of two randomised trials. Lancet 2013 Mar 9;381(9869):825-35.

26. Findlow J, Borrow R, Snape MD, Dawson T, Holland A, John TM, et al. Multicenter, openlabel, randomized phase II controlled trial of an investigational recombinant meningococcal serogroup B vaccine with and without outer membrane vesicles, administered in infancy. Clinical infectious diseases 2010;51(10):1127-37.

27. Snape MD, Dawson T, Oster P, Evans A, John TM, Ohene-Kena B, et al. Immunogenicity of two investigational serogroup B meningococcal vaccines in the first year of life: a randomized comparative trial. Pediatr Infect Dis J 2010 Nov;29(11):e71-9.

28. Prymula R, Esposito S, Vincenzo Zuccotti G, Xie F, Toneatto D, Kohl I, et al. A phase 2 randomized controlled trial of a multicomponent meningococcal serogroup B vaccine (I): Efects of prophylactic paracetamol on immunogenicity and reactogenicity of routine infant vaccines and 4CMenB. Hum Vaccin Immunother 2014 Apr 24;10(7).**

** Impact of paracetamol on the reactoogenicity of $4 \mathrm{CMenB}$ administereted with routine childhood vaccines

29. Santolaya ME, O'Ryan ML, Valenzuela MT, Prado V, Vergara R, Munoz A, et al. Immunogenicity and tolerability of a multicomponent meningococcal serogroup B (4CMenB) vaccine in healthy adolescents in Chile: a phase $2 \mathrm{~b} / 3$ randomised, observer-blind, placebocontrolled study. Lancet 2012 Feb 18;379(9816):617-24.

30. Moreira ED, Jr., Palefsky JM, Giuliano AR, Goldstone S, Aranda C, Jessen H, et al. Safety and reactogenicity of a quadrivalent human papillomavirus (types 6, 11, 16, 18) L1 viral-like-particle vaccine in older adolescents and young adults. Hum Vaccin 2011 Jul;7(7):768-75. 
31. Kimura A, Toneatto D, Kleinschmidt A, Wang H, Dull P. Immunogenicity and safety of a multicomponent meningococcal serogroup $B$ vaccine and a quadrivalent meningococcal CRM197 conjugate vaccine against serogroups A, C, W-135, and Y in adults who are at increased risk for occupational exposure to meningococcal isolates. Clin Vaccine Immunol 2011 Mar;18(3):483-6.

32. Nokleby H, Aavitsland P, O'Hallahan J, Feiring B, Tilman S, Oster P. Safety review: two outer membrane vesicle (OMV) vaccines against systemic Neisseria meningitidis serogroup B disease. Vaccine 2007 Apr 20;25(16):3080-4.

33. Mills EJ, Montori VM, Ross CP, Shea B, Wilson K, Guyatt GH. Systematically reviewing qualitative studies complements survey design: an exploratory study of barriers to paediatric immunisations. Journal of clinical epidemiology 2005 Nov;58(11):1101-8.

34. McQuaid F, Snape MD, John TM, Kelly S, Robinson H, Houlden J, et al. Persistence of Bactericidal Antibodies to 5 Years of Age Following Immunization with Serogroup B Meningococcal Vaccines at 6, 8, 12 and 40 Months of Age. Pediatr Infect Dis J 2014 Apr 9.**

** Analysis of the persistence of bactericidal antibody titers induced by 4CMenB in children immunized as infants

35. Holst J, Oster P, Arnold R, Tatley MV, Naess LM, Aaberge IS, et al. Vaccines against meningococcal serogroup B disease containing outer membrane vesicles (OMV): lessons from past programs and implications for the future. Hum Vaccin Immunother 2013 Jun; 9(6):1241-53.

36. Findlow J, Taylor S, Aase A, Horton R, Heyderman R, Southern J, et al. Comparison and correlation of neisseria meningitidis serogroup B immunologic assay results and human antibody responses following three doses of the Norwegian meningococcal outer membrane vesicle vaccine MenBvac. Infect Immun 2006 Aug;74(8):4557-65.

37. Giuliani $M M$, et al. Measuring antigen-specific bactericidal responses to a multicomponent vaccine against serogroup B meningococcus. Vaccine 2010;28:5023-30.

38. Donnelly J, Medini D, Boccadifuoco G, Biolchi A, Ward J, Frasch C, et al. Qualitative and quantitative assessment of meningococcal antigens to evaluate the potential strain coverage of protein-based vaccines. Proceedings of the National Academy of Sciences 2010;107(45):1949095.

39. Vogel U, Taha MK, Vazquez JA, Findlow J, Claus H, Stefanelli P, et al. Predicted strain coverage of a meningococcal multicomponent vaccine (4CMenB) in Europe: a qualitative and quantitative assessment. Lancet Infect Dis 2013 May;13(5):416-25.*

* Description of the MATS assay as a tool to estimate potential coverage of 4CMenB 
40. Frosi G, Biolchi A, Lo Sapio M, Rigat F, Gilchrist S, Lucidarme J, et al. Bactericidal antibody against a representative epidemiological meningococcal serogroup B panel confirms that MATS underestimates 4CMenB vaccine strain coverage. Vaccine 2013 Oct 9;31(43):4968-74.

41. Tzanakaki G, Hong E, Kesanopoulos K, Xirogianni A, Bambini S, Orlandi L, et al. Diversity of greek meningococcal serogroup B isolates and estimated coverage of the 4CMenB meningococcal vaccine. BMC microbiology 2014 Apr 29;14(1):111.

42. Bettinger JA, Scheifele DW, Halperin SA, Vaudry W, Findlow J, Borrow R, et al. Diversity of Canadian meningococcal serogroup B isolates and estimated coverage by an investigational meningococcal serogroup B vaccine (4CMenB). Vaccine 2013 Dec 17;32(1):124-30.

43. Snape MD, Philip J, John TM, Robinson H, Kelly S, Gossger N, et al. Bactericidal antibody persistence 2 years after immunization with 2 investigational serogroup B meningococcal vaccines at 6, 8 and 12 months and immunogenicity of preschool booster doses: a follow-on study to a randomized clinical trial. Pediatr Infect Dis J 2013 Oct;32(10):1116-21.

44. Santolaya ME, O'Ryan M, Valenzuela MT, Prado V, Vergara RF, Munoz A, et al. Persistence of antibodies in adolescents 18-24 months after immunization with one, two, or three doses of 4CMenB meningococcal serogroup B vaccine. Hum Vaccin Immunother 2013 Jun 28;9(11). ** ** Measure of the persistence of bactericidal antibodies induced in adolescents by 4CMenB 45. Campbell H, Andrews N, Borrow R, Trotter C, Miller E. Updated postlicensure surveillance of the meningococcal $\mathrm{C}$ conjugate vaccine in England and Wales: effectiveness, validation of serological correlates of protection, and modeling predictions of the duration of herd immunity. Clin Vaccine Immunol 2010 May;17(5):840-7.

46. Snape MD, Saroey P, John TM, Robinson H, Kelly S, Gossger N, et al. Persistence of bactericidal antibodies following early infant vaccination with a serogroup B meningococcal vaccine and immunogenicity of a preschool booster dose. Cmaj 2013 Oct 15;185(15):E715-24.

47. Pajon R, Beernink PT, Harrison LH, Granoff DM. Frequency of factor H-binding protein modular groups and susceptibility to cross-reactive bactericidal activity in invasive meningococcal isolates. Vaccine 2010 Feb 25;28(9):2122-9.

48. Masignani V, Comanducci M, Giuliani MM, Bambini S, Adu-Bobie J, Arico B, et al. Vaccination against Neisseria meningitidis using three variants of the lipoprotein GNA1870. J Exp Med 2003 Mar 17;197(6):789-99.

49. Lucidarme J, Comanducci M, Findlow J, Gray SJ, Kaczmarski EB, Guiver M, et al. Characterization of $\mathrm{fHbp}$, nhba (gna2132), nadA, porA, and sequence type in group B meningococcal case isolates collected in England and Wales during January 2008 and potential 
coverage of an investigational group B meningococcal vaccine. Clin Vaccine Immunol 2010 Jun;17(6):919-29.

50. Jacobsson S, Hedberg ST, Molling P, Unemo M, Comanducci M, Rappuoli R, et al. Prevalence and sequence variations of the genes encoding the five antigens included in the novel 5CVMB vaccine covering group B meningococcal disease. Vaccine 2009 Mar 4;27(10):1579-84.

51. Trotter CL, Maiden MC. Meningococcal vaccines and herd immunity: lessons learned from serogroup C conjugate vaccination programs. Expert Rev Vaccines 2009 Jul;8(7):851-61.

52. Read RC, Baxter D, Chadwick DR, Faust SN, Finn A, Gordon SB, et al. Effect of a quadrivalent meningococcal ACWY glycoconjugate or a serogroup B meningococcal vaccine on meningococcal carriage: an observer-blind, phase 3 randomised clinical trial. The Lancet 2014 . $^{* *}$ ** First evaluation of the potential impact of $4 \mathrm{CMenB}$ on meningococcus carriage

53. Hong E, Giuliani MM, Deghmane AE, Comanducci M, Brunelli B, Dull P, et al. Could the multicomponent meningococcal serogroup B vaccine (4CMenB) control Neisseria meningitidis capsular group X outbreaks in Africa? Vaccine 2013 Feb 4;31(7):1113-6.

54. Abad R, Luca O, Fabio R, Boccadifuocuo G, Comanducci M, Muzzi A, et al. Strain coverage of meningococcal multicomponent (4CMenB) vaccine in Spain. 18th International Pathogenic Neisseria Conference. Wurzburg, Germany 2012.

55. Nissen M, Tozer S, Whiley D, Smith H, Rockett R, Jennison A, et al. Use of the Meningococcal Antigen Typing System (MATS) to assess the Australian meningococcal strain coverage with a multicomponent serogroup B vaccine. 18th International Pathogenic Neisseria Conference. Wurzburg, Germany 2012.

56. Lemos AP, Gorla MC, Brandileone MC, Orlandi L, Rigat F, Boccadifuoco G, et al. MATS based coverage prediction for the 4CMenB Vaccine on Neisseria meningitidis B (MenB) Brazilian invasive strains. 18th Internation Pathogenic Neisseria Conference. Wurzburg, Germany 2012.

57. Claus H, Kriz P, Musilek M, Boccadifuoco G, Stella M, Frosi G, et al. Strain coverage of a multi-component meningococcus B vaccine in the Czech Republic and in Germany. 18th International Pathogenic Neisseria Conference. Wurzburg, Germany 2012.

58. Kim E, Paulos S, Carlone G, Plikaytis B, Cohn A, Messonnier N, et al. Meningococcal antigen typing system (MATS) based coverage prediction for the 4CMenB vaccine in United States. 18th International Pathogenic Neisseria Conference. Wurzburg, Germany 2012. 


\section{Drug summary box.}

\begin{tabular}{|l|l|}
\hline Drug name & Meningococcal group B (MenB) vaccine (Bexseroß) \\
\hline Status & Licensed in European Union, Canada and Australia \\
\hline Indication & Prevention of capsular group B meningococcal disease \\
\hline Mechanism of action & Induction of specific bactericidal antibodies against four \\
\hline Route of administration & Intramuscular injection \\
\hline Pivotal trials & NCT00381615: phase 2 trial in healthy infants \\
& NCT00657709, NCT00847145: phase 3 trial \\
\hline
\end{tabular}




\section{Tables}

Table 1. Summary of the clinical trials involving $4 \mathrm{CMenB}$

\begin{tabular}{|c|c|c|c|c|}
\hline $\begin{array}{l}\text { Country(s) } \\
\text { Trial number }\end{array}$ & $\begin{array}{l}\text { Age at first } \\
\text { immunisation }\end{array}$ & Schedule and number of participants enrolled for $4 \mathrm{CMenB}(\mathrm{rMenB}+\mathrm{OMV})$ intervention & phase & References \\
\hline $\begin{array}{l}\text { Switzerland } \\
\text { V72P5 }\end{array}$ & $\begin{array}{l}\text { Healthy adults } \\
18-40 \text { Years } \\
\mathrm{n}=70\end{array}$ & $\begin{array}{l}\text { Randomized } \\
\text { (I) } 3 \text { doses } 4 \text { CMenB at } 1 \text { month intervals; } \mathrm{n}=28 \\
\text { (II) } 3 \text { doses rMenB + OMVNW (Norwegian strain) at } 1 \text { month intervals; } \mathrm{n}=28 \\
\text { (III) } 3 \text { doses rMenB at } 1 \text { month intervals; } \mathrm{n}=14\end{array}$ & 1 & $\begin{array}{l}\text { Toneatto et al., } \\
\text { Human Vaccines } \\
7: 6,646-653 ; \text { June } \\
2011\end{array}$ \\
\hline $\begin{array}{l}\text { UK } \\
\text { NCT00433914 }\end{array}$ & $\begin{array}{l}\text { Healthy infants } \\
6-8 \text { Months } \\
\mathrm{n}=60\end{array}$ & $\begin{array}{l}\text { Randomized 1:1 } \\
3 \text { doses rMenB at Day 0, Day } 60 \text { and at age } 12 \text { months } n=30 \text {. } \\
3 \text { doses } 4 \text { CMenB at Day 0, Day } 60 \text { and at age } 12 \text { months } n=30 \\
\text { Participants also received routine vaccines at } 12 \text { months in the opposite thigh to } 4 \mathrm{CMenB} \text {. } \\
1\end{array}$ & 2 & $\begin{array}{l}\text { Snape et al., Pediatr } \\
\text { Infect Dis J 2010;29: } \\
\text { e71-e79) }\end{array}$ \\
\hline $\begin{array}{l}\text { UK } \\
\text { NCT00381615 }\end{array}$ & $\begin{array}{l}\text { Healthy infants } \\
2 \text { or } 12 \text { Months } \\
\mathrm{n}=147\end{array}$ & $\begin{array}{l}\text { Randomly allocated 2:2:1:1 } \\
3+1 \text { doses rMenB at 2, } 46 \text { and } 12 \text { months of age } n=48 \\
3+1 \text { doses } 4 \text { CMenB at } 2,46 \text { and } 12 \text { months of age } n=50 \\
1 \text { Dose rMenB at } 12 \text { months } n=25 . \\
1 \text { Dose } 4 \text { CMenB at } 12 \text { months } n=24 \\
\text { Participants also received routine vaccinations } 2\end{array}$ & 2 & $\begin{array}{lr}\text { Findlow } & \text { et } \quad \text { al., } \\
\text { Clinical } & \text { Infectious } \\
\text { Diseases } & 2010 ; \\
51(10): 1127-1137\end{array}$ \\
\hline $\begin{array}{l}\text { UK } \\
\text { NCT01027351 }\end{array}$ & $\begin{array}{l}\text { Healthy infants } \\
40-44 \text { Months } \\
\mathrm{n}=113\end{array}$ & $\begin{array}{l}\text { Follow on study to trial NCT00381615 } \\
\text { Previous rMenB at 2, } 46 \text { and } 12 \text { months; } 1 \text { booster } \mathrm{n}=29 \\
\text { Previous } 4 \text { CMenB at 2, } 46 \text { and } 12 \text { months; } 1 \text { booster } \mathrm{n}=19\end{array}$ & 2 & $\begin{array}{l}\text { Snape et al., CMAJ } \\
\text { 2013. DOI: } 10.1503 \\
\text { /cmaj.130257 }\end{array}$ \\
\hline
\end{tabular}


Previous rMenB at 12 months; 2 boosters $n=14$

Previous $4 \mathrm{CMenB}$ at 12 months; 2 boosters $\mathrm{n}=8$

Age matched naïve controls 2 doses at day 0 and 2 months $n=43$

\begin{tabular}{|c|c|c|c|c|}
\hline UK & Healthy infants & Follow on study to trial NCT00433914 & 2 & Snape et al., Pediatr \\
\hline NCT01026974 & $\begin{array}{l}\text { 40-44 Months } \\
\mathrm{n}=71\end{array}$ & $\begin{array}{l}\text { Previous rMenB at } 6,8 \text { and } 12 \text { months; } 1 \text { booster } \mathrm{menB} n=16 \\
\text { Previous } 4 \mathrm{CMenB} \text { at } 6,8 \text { and } 12 \text { months; } 1 \text { booster } 4 \mathrm{CMenB} n=14 \\
\text { MenB vaccine naïve age matched controls; } 2 \text { doses } 4 \text { CMenB } 60 \text { days apart } n=41\end{array}$ & & $\begin{array}{l}\text { Infect Dis J } \\
\text { 2013;32:1116-1121 }\end{array}$ \\
\hline $\begin{array}{l}\text { Italy and Germany } \\
\text { NCT00560313 }\end{array}$ & $\begin{array}{l}\text { Healthy adults } \\
18-50 \text { Years } \\
\mathrm{n}=54\end{array}$ & $\begin{array}{l}3 \text { doses of } 4 \text { CMenB at Day } 0,2 \text { months and } 6 \text { months followed by } 1 \text { dose of MenACWY- } \\
\text { CRM } 1 \text { month later } n=54\end{array}$ & 2 & $\begin{array}{l}\text { Kimura et al., CVI, } \\
\text { Mar. } 2011\end{array}$ \\
\hline $\begin{array}{l}\text { Belgium, UK, } \\
\text { Czech Republic, } \\
\text { Germany, } \\
\text { Italy and Spain } \\
\text { NCT00721396 }\end{array}$ & $\begin{array}{l}\text { Healthy Infants } \\
2 \text { Months } \\
\mathrm{n}=1885\end{array}$ & $\begin{array}{l}\text { Randomized } 2: 2: 1: 1 \\
\text { concomitant } 3 \text { doses of } 4 \mathrm{CMenB} \text { at } 2,4 \text {, and } 6 \text { months with routine vaccines } 3 \mathrm{n}=622 \\
\text { intercalated } 3 \text { doses of } 4 \mathrm{CMenB} \text { at } 2,4 \text {, and } 6 \text { months with routine vaccines at } 3,5 \text {, and } \\
7 \text { months } n=632 \\
\text { Accelerated } 4 \mathrm{CMenB} \text { with routine vaccines at } 2,3 \text {, and } 4 \text { months } n=317 \text {. } \\
\text { Routine vaccines only at } 2,3 \text { and } 4 \text { months }\end{array}$ & $2 b$ & $\begin{array}{l}\text { Gossger et al., } \\
\text { JAMA. } \\
\text { 2012;307(6):573- } \\
582\end{array}$ \\
\hline $\begin{array}{l}\text { Chile } \\
\text { NCT00661713. }\end{array}$ & $\begin{array}{l}\text { Healthy } \\
\text { adolescents } \\
\text { 11-17 Years } \\
\mathrm{n}=1631\end{array}$ & $\begin{array}{l}\text { Randomized 3:3:3:3:1 } \\
1 \text { dose of } 4 \text { CMenB } n=375 \text { with/without boost at month } 6 n=114 / 212 \text { respectively } \\
2 \text { doses of } 4 \text { CMenB } 1 \text { month apart } n=375 \text { with/without boost at month } 6 n=112 / 225 \\
\text { respectively } \\
2 \text { doses of } 4 \text { CMenB } 2 \text { months apart } n=380 \text { with/without boost at month } 6 n=111 / 222 \\
\text { respectively } \\
3 \text { doses of } 4 \text { CMenB } 1 \text { month apart } n=373\end{array}$ & $2 b / 3$ & $\begin{array}{l}\text { Santolaya et al., } \\
\text { Lancet 2012; 379: } \\
617-24\end{array}$ \\
\hline
\end{tabular}


3 doses placebo $n=128$ with 1 dose of 4 CMenB at month $6 n=119$

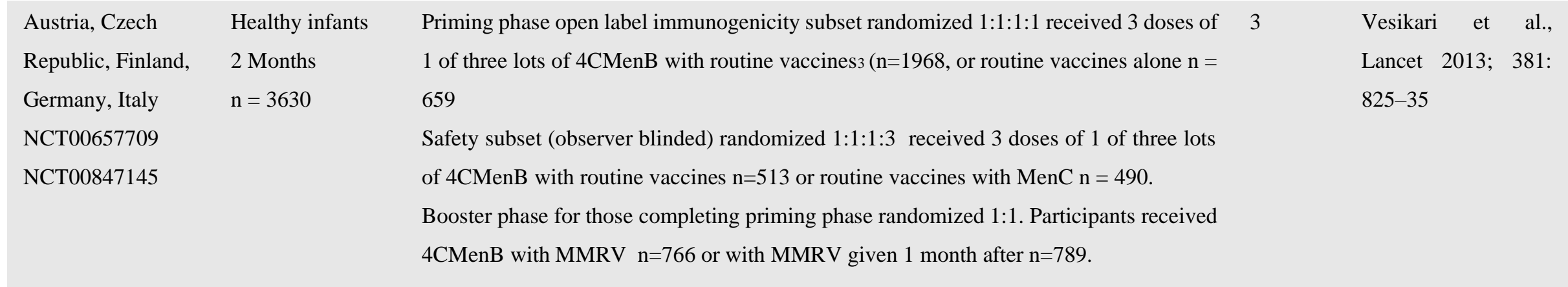

${ }^{1}$ a combined Haemophilus influenzae type B and meningococcal serogroup C glycoconjugate vaccine (Menitorix, GSK, Belgium)

${ }^{2}$ diphtheria-tetanus-acellular pertussis- Haemophilus influenzae type b (Hib) and inactivated poliovirus vaccine (Pediacel: Sanofi Pasteur) at 2, 3, and 4 months of age, pneumococcal conjugate vaccine (Prevenar; Wyeth Pharmaceuticals) at 2, 4, and 13 months of age, meningococcal serogroup C (MenC) conjugate vaccine (Menjugate; Novartis) at 3 and 5 months of age, MenC-Hib conjugate vaccine (Menitorix; GSK Biologicals) at 12 months of age, and measles, mumps, rubella vaccine (Priorix; GSK Biologicals) at 13 months of age.

${ }^{3}$ Routine vaccines: 7-valent pneumococcal and combined diphtheria, tetanus, acellular pertussis, inactivated polio, hepatitis B, Haemophilus influenzae type b vaccines. 
Table 2. Summary of key safety and reactogenicity findings during phase $2 \mathrm{~b} / 3$ trials in infants comparing regimens of co-administration of 4 CMenB with routine vaccines vs. routine vaccines alone.

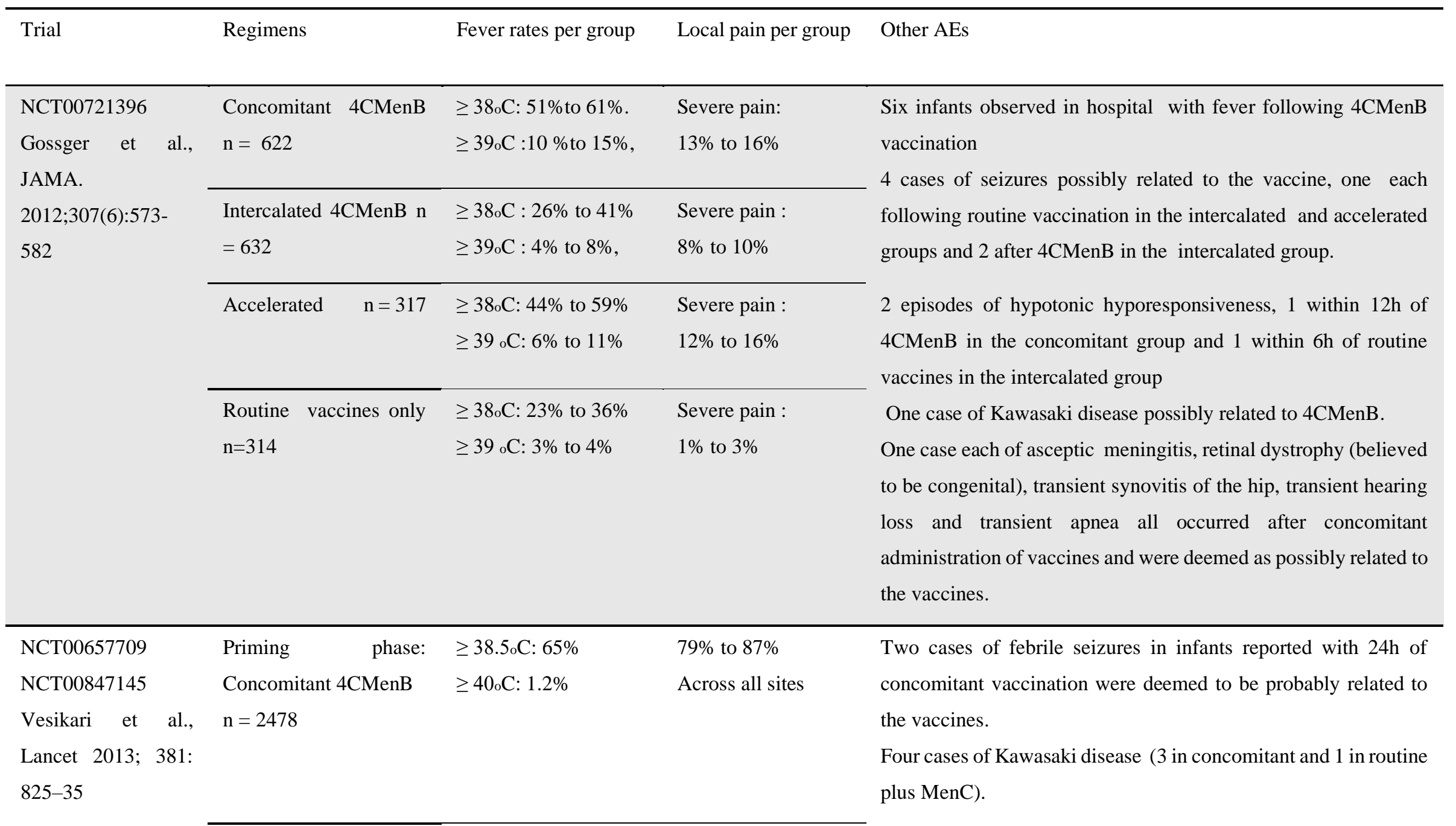




\begin{tabular}{|c|c|c|c|}
\hline $\begin{array}{l}\text { Routine vaccine, } \\
\mathrm{n}=659\end{array}$ & $\begin{array}{l}\geq 38.5 \circ \mathrm{oC}: 32 \% \\
\geq 40 \mathrm{oC}: 0 \%\end{array}$ & $\begin{array}{l}53 \% \text { to } 59 \% \\
\text { Across all sites }\end{array}$ & \\
\hline $\begin{array}{l}\text { routine vaccines with } \\
\text { MenC } \\
\mathrm{n}=490 \text {. }\end{array}$ & $\begin{array}{l}\geq 38.5 \mathrm{oC}: 34 \% \\
\geq 40 \mathrm{oC}: 0.2 \%\end{array}$ & $\begin{array}{l}54 \% \text { to } 68 \% \\
\text { Across all sites }\end{array}$ & \\
\hline $\begin{array}{l}\text { Booster phase : } \\
\text { Concomitant with } \\
\text { MMRV } \\
\mathrm{n}=766\end{array}$ & $\geq 38.0 \circ \mathrm{C}: 30.6 \%$ & & $\begin{array}{l}\text { One case of pyrexia during concomitant boost with MMRV were } \\
\text { reported as possibly related to the vaccines }\end{array}$ \\
\hline $\begin{array}{l}\text { MMRV given } 1 \text { month } \\
\text { after } \\
\mathrm{n}=789\end{array}$ & $\geq 38.0 \mathrm{oC}: 31.6 \%$ & & \\
\hline $\begin{array}{l}\text { Priming phase } \\
\text { I concomitant } 4 \mathrm{CMenB} \\
\mathrm{n}=188\end{array}$ & $\begin{array}{l}\geq 38 \mathrm{o}: 57 \% \text { to } 77 \% \\
\geq 39{ }_{\circ} \mathrm{C}: 7 \% \text { to } 21 \%\end{array}$ & $\begin{array}{l}\text { Severe pain: } 9 \% \\
\text { to } 15 \%\end{array}$ & $\begin{array}{l}\text { Medically attended fever rates ranged from } 0 \% \text { to } 4 \%, 0 \% \text { to } 1 \% \\
\text { and } 1 \% \text { to } 2 \% \text { in groups I, II and III respectively across the } \\
\text { primary course of vaccinations }\end{array}$ \\
\hline $\begin{array}{l}\text { II concomitant } 4 \mathrm{CMenB} \\
+ \text { paracetamol } n=184\end{array}$ & $\begin{array}{l}\geq 38{ }_{\circ} \mathrm{C}: 37 \% \text { to } 57 \% \\
\geq 39{ }_{\circ} \mathrm{C}: 3 \% \text { to } 6 \%\end{array}$ & Severe pain: & $\begin{array}{l}\text { No serious adverse events were deemed to be related to study } \\
\text { vaccines. }\end{array}$ \\
\hline $\begin{array}{l}\text { III concomitant MenC } \mathrm{n} \\
=186\end{array}$ & $\begin{array}{l}\geq 38{ }_{\circ} \mathrm{C}: 24 \% \text { to } 39 \% \\
\geq 39{ }_{\circ} \mathrm{C}: 1 \% \text { to } 5 \%\end{array}$ & $\begin{array}{l}\text { Severe pain: } 1 \% \\
\text { to } 3 \%\end{array}$ & \\
\hline $\begin{array}{l}\text { Booster phase } \mathrm{n}=500 \\
\text { One dose of } 4 \mathrm{CMenB} \\
\text { all groups }\end{array}$ & $\begin{array}{l}\geq 38 \mathrm{oC}: 70 \%, \quad 60 \% \\
\text { and } 66 \% \text { in groups I, } \\
\text { II and III respectively }\end{array}$ & $\begin{array}{l}\text { Severe pain: } 20 \% \text {, } \\
14 \% \text { and } 20 \% \text { in }\end{array}$ & \\
\hline
\end{tabular}


groups I, II and III

respectively

For further details of the trials and the routine vaccinations see foot notes in Table 1. 
Table 3. Predicted strain coverage by country using MATS

\begin{tabular}{llll}
\hline Country & Number of strains tested & $\begin{array}{l}\text { Predicted strain coverage (95\% } \\
\text { CI) }\end{array}$ & Reference \\
\hline England and Wales & & $73 \%(57-87)$ & \\
France & & $85 \%(69-83)$ & \\
Germany & 1052 & $82 \%(69-92)$ & 39 \\
Italy & & $87 \%(70-93)$ & \\
Norway & & $85 \%(76-98)$ & 41 \\
Czech Republic & & $74 \%(58-87)$ & 54 \\
Spain & 148 & $69 \%(48-85)$ & 55 \\
\hline Greece & 300 & $89.2 \%(63.5-98.6 \%)$ & 56 \\
\hline Spain & 373 & $68.7 \%(48-85.3)$ & 57 \\
\hline Australia & 99 & $76 \%(63-87)$ & 57 \\
\hline Brazil & 108 & $80.8 \%(70.7-94.9)$ & 58 \\
\hline Czech Republic & 222 & $74 \%(59-87)$ & 42 \\
\hline Germany & 442 & $81 \%(71-93)$ & \\
\hline USA & 157 & $91.2 \%(72.2-95.9)$ & $66 \%(46-78)$ \\
\hline Canada & & & 57 \\
\hline
\end{tabular}


Table 4. hSBA GMTs against four target strains observed following various infant and teenager immunisation schedules

\begin{tabular}{|c|c|c|c|c|c|c|c|c|}
\hline \multirow{2}{*}{$\begin{array}{l}\text { Study cohort } \\
\text { (Age at baseline) }\end{array}$} & \multirow{2}{*}{$\begin{array}{l}\text { No. of } \\
\text { immunisation } \\
\text { s administered }\end{array}$} & \multirow{2}{*}{$\begin{array}{l}\text { Time immunisation } \\
\text { administered post } \\
\text { baseline (months) }\end{array}$} & & \multicolumn{4}{|c|}{ SBA Geometric Mean Titres (95\% CI) } & \multirow[t]{2}{*}{ Ref. } \\
\hline & & & & 44/76-SL & $5 / 99$ & NZ98/254 & M10713 & \\
\hline \multirow{7}{*}{$\begin{array}{l}\text { Infants } \\
\text { ( } 2 \text { months) }\end{array}$} & \multirow{7}{*}{5} & \multirow{7}{*}{$0,2,4,10,38-42$} & Pre-immunisation & $1.4(1.2-1.7)$ & $1.2(1.0-1.3)$ & $1.4(1.1-1.8)$ & $2.6(1.8-3.7)$ & \multirow{7}{*}{26,43} \\
\hline & & & One month post 2 nd dose & $28.0(19-40)$ & $6.6(4.8-9.0)$ & $104.0(64.0-169.0)$ & $2.1(1.4-3.1)$ & \\
\hline & & & One month post 3 rd dose & $30(19-46)$ & $19(11-33)$ & $126.0(77.0-205.0)$ & $4.1(2.6-6.3)$ & \\
\hline & & & 6 months post 3 rd dose & $4.5(2.9-7.0)$ & $2.4(1.5-3.9)$ & $25.0(13.0-47.0)$ & $1.8(1.2-2.7)$ & \\
\hline & & & One month post booster & $106.0(71-159)$ & $29.0(15.0-56.0)$ & $629.0(324.0-1219.0)$ & $4.9(2.8-8.5)$ & \\
\hline & & & 28 months post-first booster & $5.3(3.3-8.8)$ & $28(9.4-83)$ & $2.8(1.4-5.6)$ & $5.3(2.3-12)$ & \\
\hline & & & One month post-second booster & $89(68-116)$ & 1708 & $47(20-107)$ & $39(22-69)$ & \\
\hline \multirow{6}{*}{$\begin{array}{l}\text { Infants } \\
\text { (6 months) }\end{array}$} & \multirow{6}{*}{4} & \multirow{6}{*}{$0,2,6,34-38$} & Pre-immunisation & $1.70(1.29-2.24)$ & $1.05(0.98-1.12)$ & $1(1-1)$ & & \multirow{6}{*}{$27,34,43$} \\
\hline & & & One month post 2 nd dose & $250(173-361)$ & $534(395-721)$ & $27(21-36)$ & Not tested & \\
\hline & & & One month post 3 rd dose & $189(136-263)$ & $906(700-1172)$ & $44(32-62)$ & & \\
\hline & & & 28 months post 3 rd dose & $2.55(1.15-5.66)$ & $29(18-47)$ & $1.74(0.91-3.33)$ & $7.11(3.61-14)$ & \\
\hline & & & One month post booster & $114(59-222)$ & $926(432-1988)$ & $32(14-71)$ & $23(13-41)$ & \\
\hline & & & 20 months post booster & $4.69(1.98-11)$ & $119(56-252)$ & $1.63(0.86-3.08)$ & $5.51(2.19-14)$ & \\
\hline Teenagers & \multirow{3}{*}{1} & \multirow{3}{*}{0} & Pre-immunisation & $4.0(3.1-5.1)$ & $2.7(2.2-3.3)$ & $2.7(2.1-3.4)$ & \multirow{9}{*}{ Not tested } & \multirow{9}{*}{44} \\
\hline (approximately & & & One month post immunisation & $52(42-63)$ & $65(53-79)$ & $36(29-45)$ & & \\
\hline 16 years) & & & 18-24 months post immunisation & $29(20-42)$ & $8.0(6.2-10)$ & $8.9(6.7-12)$ & & \\
\hline Teenagers & \multirow{3}{*}{2} & 0,1 & Pre-immunisation & $3.0(2.5-3.6)$ & $2.3(2.0-2.7)$ & $2.4(2.0-2.9)$ & & \\
\hline (approximately & & 0,2 & One month post second immunisation & $211(181-247)$ & $610(523-710)$ & $104(88-123)$ & & \\
\hline 16 years) & & 0,6 & 18-24 months post second immunisation & $31(24-39)$ & $46(38-55)$ & $20(16-24)$ & & \\
\hline Teenagers & \multirow{3}{*}{3} & $0,1,2$ & Pre-immunisation & $3.5(2.9-4.3)$ & $2.4(2.0-2.8)$ & $2.8(2.3-3.3)$ & & \\
\hline (approximately & & $0,1,6$ & One month post second immunisation & $268(230-312)$ & $790(679-920)$ & $146(124-172)$ & & \\
\hline 16 years) & & $0,2,6$ & 18-24 months post second immunisation & $44(35-55)$ & $86(72-104)$ & $30(24-37)$ & & \\
\hline
\end{tabular}


